\title{
Implementation of 21st-Century Learning on Psychomotor Learning Outcomes in Science Materials With Learning Motivation as Co-Variable
}

\author{
Dian Meilani ${ }^{1 *}$ Ummu Aiman $^{2}$
}

\author{
${ }^{1,2}$ Department Of Elementary Teacher Education, Universitas Muhammadiyah Kupang,Jl. K. H. \\ Ahmad Dahlan, Kayu Putih, Kupang City, East Nusa Tenggara, Indonesia \\ "Corresponding author. Email: dianmeilani99@gmail.com
}

\begin{abstract}
Learning outcomes are a reference to the extent to which students succeed. Psychomotor learning outcomes are an important aspect of learning outcomes related to motor skills. The low psychomotor learning outcomes, especially in elementary school science material, demands to be completed one way by applying $21^{\text {st }}$ century learning. This study aims to determine the effect of the implementation of $21^{\text {st }}$ century learning on psychomotor learning outcomes in natural science material with learning motivation covariables. This research is an experimental study with a single factor independent group design with the use of Covariate. Data analysis used One Way ANOVA, ANACOVA test, and Product Moment Test. Hypothesis test results show $\mathrm{F}_{\mathrm{A}}>$ Ftable, namely 12.02> 4.00, then $\mathrm{F}_{\mathrm{A}}^{*}>\mathrm{F}$ table, namely 17.99> 4.00 and with a contribution of $74 \%$. Thus it can be concluded that using $21^{\text {st }}$ century learning can improve student psychomotor learning outcomes in natural science material, even after learning motivation is controlled.
\end{abstract}

Keywords: 21st-century learning, psychomotor learning outcomes in science materials, learning motivation

\section{INTRODUCTION}

Learning outcomes are the abilities that students have after receiving a learning experience. In the learning process, the learning outcomes are important because they become a reference to determine the extent of the success of students in the learning activities that have been implemented [4]. Learning outcomes consist of 3 aspects, one of which is psychomotor. This aspect relates to motor skills, where the manipulation of objects or activities that require coordination of nerves and bodies [7].

The low learning outcomes, especially in science material in elementary schools, are a separate problem that must be resolved. The factors that cause these problems include the lack of varied learning [11], the passivity of students in learning [19] and the lack of innovation in learning [14].

Other factors that occur in the field are related to the low psychomotor learning outcomes of the fifth grade students of SD Muhammadiyah 2 Kupang for the 2019/2020 academic year, including: a) conventional learning; b) limited learning resources; c) educators as a learning center (teacher centered) so that students are more passive; d) students are not used to using abilities according to the demands of the century, namely the ability to recognize problems, solve problems, think, argue, make decisions about changes, and communicate. Therefore, the abilities of students are left behind.
Overcoming these problems, it is necessary to apply learning in accordance with the demands of the current century, namely $21^{\text {st }}$ century learning, where learning that requires a strong understanding of knowledge is then supported by various skills, expertise and literacy needed by an individual [8]. This is a learning that combines a scientific approach with $21^{\text {st }}$ century skills, namely $4 \mathrm{C}$ learning and innovation skills.

According to [2] the scientific approach is an approach consisting of 5 aspects, namely observing, questioning, reasoning, associating and communicating. meanwhile, 4C learning and innovation skills are $21^{\text {st }}$ century skills consisting of critical thinking and problem solving, creativity and innovation, communication, and collaboration [9; 17]. This is in line with [10] where the 4C skills contained in $21^{\text {st }}$ century learning help students to develop and demonstrate good understanding and greater effectiveness and efficiency in Career and Life skills as well as Information, Media and Technology skills.

Efforts to improve psychomotor learning outcomes in science learning are not only with applied learning but there are internal factors that support, namely learning motivation. Motivation to learn as an encouragement that arises in every student to get good results [5].

The objectives of this study were 1) To determine the effect of the implementation of $21^{\text {st }}$ century learning on psychomotor learning outcomes in natural science material of students. 2) To determine the effect of the 
implementation of $21^{\text {st }}$ century learning on psychomotor learning outcomes in natural science material of students after learning motivation is controlled. 3) To find out how much the significant contribution of learning motivation to psychomotor learning outcomes in students' natural science material.

The hypotheses of this study are 1) there is an effect of the implementation of $21^{\text {st }}$ century learning on psychomotor learning outcomes in natural science material of students. 2) there is an effect of the implementation of $21^{\text {st }}$ century learning on psychomotor learning outcomes in students' natural science material after learning motivation is controlled. 3) significant contribution of learning motivation to psychomotor learning outcomes in students' natural science material.

\section{MATERIAL AND METHOD}

2.1 Types of research

This research used an experimental research study design with Single Factor Independent Groups Design using Covariate.

2.2 Time and Place of Research

This research was conducted at Muhammadiyah 2 Kupang Elementary School 2019/2020 school year.

2.3 Population and Sample

The population were 92 students of SD Muhammadiyah 2 Kupang grade $\mathrm{V}$ and the sample used consisted of 62 people which determined using random sampling techniques. Class VA determined as an experiment class totaled 30 students and class VC as control class totaled 32 students.

2.4 Research Variables

There are three variables in this research namely independent variable, dependent variable and control variable (covariable). Independent variable in this research is $21^{\text {st }}$ century learning. Dependent variable in this research is the learning outcome in natural sciences material. The control variable in this research is learning motivation.

2.5 Data Analysis

Data collection method used a test method in the form of skills tests for psychomotor learning outcomes in natural science material and a nontest method in the form of a questionnaire for learning motivation. The research data were analyzed in stages through descriptive analysis, prerequisite test analysis, and hypothesis test. Descriptive analysis was conducted to analyze the data of science learning outcomes and student motivation. While the intended prerequisites test analysis were normality test, homogeneity test and linearity test. The hypothesis test used were One Way ANAVA, ANAKOVA, and Product Moment.

\section{RESULT AND DISCUSSION}

The full hypothesis test results are in the following table: Table 1. One Way Anava Test

\begin{tabular}{llllllll}
\hline $\begin{array}{l}\text { Source of } \\
\text { Variation }\end{array}$ & NS & df & ANS & $\mathbf{F}_{\text {A }}$ & $\begin{array}{c}\mathbf{F} \\
\text { Table } \\
\mathbf{5 \%}\end{array}$ & Notes \\
\hline Between & 931.00 & 1 & 931.00 & 12.02 & 4.00 & Sig. \\
Within & 4648.74 & 60 & 77.479 & - & - & - \\
Total & 354930 & 62 & - & - & - & - \\
\hline
\end{tabular}

Notes:

df: Degrees of freedom

NS: Number of Squares

ANS: Average number of squares

Sig: Significant

Table 1. the first hypothesis test shows that the score $\mathrm{F}_{\mathrm{A}}=$ 12.02 while $\mathrm{F}_{\text {table }}(0.05 ; 1: 60)=4.00$. This means $\mathrm{F}_{\mathrm{A}}>$ $F_{\text {table }}$. then there is an effect of the implementation of $21 \mathrm{st}$ century learning on psychomotor learning outcomes in science material of students. The conclusion drawn from the hypothesis test is that applying $21^{\text {st }}$ century learning can improve science learning outcomes. $21^{\text {st }}$ Century learning is a learning that integrates $21^{\text {st }}$ century skills with a scientific approach. This learning results in students not only being formed with a scientific sequence during learning but also formed by cultivating $21^{\text {st }}$ century skills, namely learning skills and innovating 4C in accordance with the development and demands of the era [8].

Learning that involves learning and $4 \mathrm{C}$ innovating skills forms students to think critically to solve problems and try to solve problems by gathering information (critical thinking); students are encouraged to literate in literacy activities carried out as a form (communication); students are trained to work in doing work or completion (collaboration); and students are accustomed to creating creations that are practical, effective, simple and easy to use (Creative) $[8 ; 9 ; 13]$

This research is relevant to [18] who said that learning to use a scientific approach in the integrated Problem Based Learning model with the cultivation of $4 \mathrm{C}$ skills has higher higher-order thinking abilities than those who learn to use a scientific approach in Think-Pair-Share model learning with the cultivation of $4 \mathrm{C}$ skills. Research [15] shows that creative thinking has a positive effect on learning achievement.

Table 2. Ancova Test

\begin{tabular}{ccccccc}
\hline $\begin{array}{c}\text { Source of } \\
\text { Variation }\end{array}$ & NS & df & ANS & $\mathbf{F}_{\mathbf{A}}^{*}$ & $\begin{array}{c}\mathbf{F} \\
\text { Table } \\
5 \%\end{array}$ & Notes \\
\hline Between & 43.477 & 1 & 43.477 & 17.99 & 4.00 & Sig. \\
Within & 1426.011 & 59 & 24.170 & - & - & - \\
Total & 35493.000 & 62 & - & - & - & - \\
\hline
\end{tabular}

Notes:

df: Degrees of freedom

NS: Number of Squares

ANS: Average number of squares

Sig: Significant 
Hypothesis test two in table 2. obtained $\mathrm{F}_{\mathrm{A}}^{*}=17.99$ while $\mathrm{F}_{\text {Table }}(0.05 ; 1: 59)=4.00$. This means $F_{A}^{*}>F_{\text {table }}$. So, there is an effect of the implementation of $21^{\text {st }}$ century learning on psychomotor learning outcomes in natural students' science material after learning motivation is controlled. Motivation to learn as the actualization of individual goals under certain conditions that focus on readiness or willingness to change [16].

Students' learning motivation includes aspects: Persistence in learning, resilience in facing difficulties, interest and focus of attention in learning, achievement and independent in learning [1].

In the learning process, learning motivation has an impact on learning outcomes, so that after learning motivation is controlled there is an increase in the $F$ value of 1.158, this further optimizes 21st century learning, therefore the learning motivation factor needs to be considered in improving learning outcomes.

In line with research from [2] which states that learning motivation has a great influence on learning outcomes.

Table 3. Product Moment Test

\begin{tabular}{lcccccc}
\hline Source & $\mathbf{t}$ & Sig. & $\mathbf{r}$ & $\mathbf{R}^{\mathbf{2}}$ & Decisions & Contribution \\
\hline Ex & 5.3 & $\mathrm{p}<0.05$ & 0.705 & 0.45 & Sig. & $45 \%$ \\
Cont & 16.6 & $\mathrm{p}<0.05$ & 0.949 & 0.90 & Sig. & $90 \%$ \\
Tot & 12.6 & $\mathrm{p}<0.05$ & 0.858 & 0.74 & Sig. & $74 \%$ \\
\hline
\end{tabular}

Notes:

Ex: Experiment

Cont: Control

Tog: Together

Sig: Significant

Table 3. for hypothesis three shows that the contribution of learning motivation to learning outcomes is $74 \%$. Thus, the amount of motivation of students in learning is directly proportional to the psychomotor learning outcomes obtained. This is in line with [5] which states that the greater the motivation to learn, the higher the learning outcomes.

\section{CONCLUSION}

Based on the results of the hypothesis test, it is concluded that: 1) there is an effect of the implementation of $21 \mathrm{st}$ century learning on psychomotor learning outcomes in students' natural science material with $\mathbf{F}_{\mathbf{A}}=12.02$. 2) there is an effect of the implementation of $21^{\text {st }}$ century learning on psychomotor learning outcomes in students' natural science material after learning motivation is controlled with $\mathbf{F}_{A}^{*}=17.99$. 3) significant contribution of learning motivation to psychomotor learning outcomes in students' natural science material of by $74 \%$.

\section{REFERENCES}

[1]Afandi, R. (2015). Pengembangan Media Pembelajaran Permainan Ular Tangga Untuk Meningkatkan Motivasi Belajar Siswa dan
Hasil Belajar IPS di Sekolah Dasar. JURNAL INOVASI PEBELajaran (JINoP), Vol.1, No. 1, 2015 (halaman 77-89).

[2]Ambarsari, Desi. (2016). implementasi pendekatan saintifik untuk meningkatkan keterampilan mengkomunikasikan dan prestasi belajar IPA siswa kelas IV SD. Jurnal Pendidikan Guru Sekolah Dasar Edisi 12 Tahun ke-5 2016.

[3] Aritonang, K. T. (2008). Minat dan motivasi dalam meningkatkan hasil belajar siswa. Jurnal Pendidikan Penabur, 7(10), 11-21.

[4] Chania, Y., Haviz, M., Sasmita, D. 2016. Hubungan Gaya Belajar Dengan Hasil Belajar Peserta didik Pada Pembelajaran Biologi Kelas X Sman 2 Sungai Tarab Kabupaten Tanah Datar. Journal of Sainstek, Vol.8, No. 1, tahun 2016 (halaman 77-84).

[5] Damis dan Muhajis. (2018). Analisis Hubungan Antara Motivasi Belajar Dengan Hasil Belajar Siswa Pada Sekolah Dasar Negeri 3 Allakuang Kecamatan Maritengngae Kabupaten Sidenreng Rappang. Jurnal Idaarah, 2(2), hlm 216-228.

[6] Daryanto dan Karim. (2017). Pembelajaran abad 21. Yogyakarta: Gava Media.

[7] Dimyati \& Mudjiono. 2013. Belajar Dan Pembelajaran. Jakarta: Rineka Cipta.

[8] Kivunja, C. (2014a). Do You Want Your Students to Be Job-Ready with 21st Century Skills? Change Pedagogies: A ParadigmShift from Vygotskyian Social Constructivism to Critical Thinking, Problem Solving and Siemens' Digital Connectivism.International Journal of Higher Education, 3, 81-91.

[9]Kivunja, C. (2014b). Innovative Pedagogies in Higher Education to Become Effective Teachers of 21st Century Skills: Unpackingthe Learning and Innovations Skills Domain of the New Learning Paradigm. International Journal of Higher Education, 3, 37-48.

[10] Kivunja, Charles. 2015. Exploring the Pedagogical Meaning and Implications of the 4Cs " Super Skills " for the 21 st Century through Bruner's $5 \mathrm{E}$ Lenses of Knowledge Construction to Improve Pedagogies of the New Learning Paradigm. Creative Education, 2015, 6, hlm 224-239.

[11] Meilani,D.,Dantes,N., \& Tika, I. N. (2020). Pengaruh Implementasi Pembelajaran Saintifik Berbasis Keterampilan Belajar dan Berinovasi 4C terhadap Hasil Belajar IPA dengan Kovariabel Sikap Ilmiah pada Peserta Didik Kelas V SD Gugus 15 Kecamatan Buleleng. Jurnal Elementary: Kajian Teori dan Hasil Penelitian Pendidikan Sekolah Dasar, 3(1), 15.

[12] P21. 2015. P21 Framework Definitions. http://www.21stcenturyskills.org. Diakses tanggal 23 Januari 2020. 
[13] Ridong Hu, Yi-Yong Wu \& Chich-Jen Shieh. 2016. Effects of Virtual Reality Integrated Creative Thinking Instruction on Students' Creative Thinking Abilities. iSER Eurasia Journal of Mathematics, Science \& Technology Education, 2016, 12(3), 477486.

[14] Sarjani, Marhaeni, dan Tika. (2014). Pengaruh Pembelajaran Kooperatif Teknik Peta Konsep Terhadap Hasil Belajar IPA peserta didik kelas V SD 4 Tuban Dengan Kovariabel Sikap Ilmiah. e-Journal Program Pascasarjana Universitas Pendidikan Ganesha Program Studi Pendidikan Dasar, Vol.4 Tahun 2014, hlm 1-10.

[15] Supardi. (2015). Peran Berpikir Kreatif Dalam Proses Pembelajaran Matematika. Jurnal Pendidikan Dasar, 6(2) hlm 222-231.

[16]Tentama,et. Al.(2019). Motivation to learn and social support determine employability among vocational high school students. International Journal of Evaluation and Research in Education (IJERE) Vol. 8, No. 2, June 2019, pp. 237 242

[17] Trilling, B., \& Fadel, C. (2009). 21st Century Skills: Learning for Life in Our Times. San Francisco, CA: Jossey-Bass.

[18] Widiawati, dkk. (2018). Higher Order Thinking Skills as Effect of Problem Based Learning in the 21st Century Learning. International Journal of Multicultural and Multireligious Understanding (IJMMU), Vol. 5, No. 3, June, hlm 96-105.

[19] Yusnaeni, Herawati, S., A.D. Corebima, Siti, Z. (2016). Hubungan Kemampuan Berpikir Kreatif DanHasil Belajar Kognitif Pada Pembelajaran Search Solve Create and Solve Di SMA. Prosiding Seminar Nasional Biologi 2016, hlm 443-446. 